\title{
The [0]ther Analogia and the Trace of 'God'
}

Mark Joseph T. Calano

\begin{abstract}
Quite broadly, analogia can be understood as a mode of presenting and (re)presenting the play between similarity and dissimilarity, being and other, and identity and difference. While Thomas Aquinas might have started the possibility of speaking of (and about) God analogically, this mode of (re)presenting can be better understood within a metaphysical system that gives primacy to being; in relation to this, recent emphasis in philosophy of the ethical relationship with the other seems to have put into question not only the metaphysical primacy of being but (by association) the analogical possibility of referring to God. Within this context and in this paper, I argue for the possibility of still (re)presenting God in an analogical way by understanding the play between being and difference that is constitutive of the movement of analogia. The paper is divided into three parts. The first part discusses analogia in relation to both the metaphysical privileging of 'being' and its possible applications to God. In the second part, we investigate the [other] possibility of understanding analogia in terms of an ethical relationship with an 'other' and its consequence of im/possibly naming God. The third part engages the dynamics between the two aforementioned emphases in analogia in its attempt to (re)present the metaphysical 'being' and the ethical 'other.' It further situates the trace of God within the need to reunderstand analogia within this possible overcoming of metaphysics.
\end{abstract}

Keywords: Thomas Aquinas, Levinas, Derrida, analogia

\section{Introduction}

$A$ nalogia, since Thomas Aquinas and as pushed further by Thomas Cajetan and Francisco Suárez, plays a significant role in the determination of and in the understanding of the relationship between the metaphysical system that privileges 'being' and God. But paradigm shifts and emphasis on the ethical relationship with the 'other' has complicated further any analogical discourse about the im/possibility of

(c) 2019 Mark Joseph T. Calano

https://www.kritike.org/journal/issue 25/calano december2019.pdf

ISSN 1908-7330 
(re)presenting God. Etymologically, the word analogia comes from two Greek words ana and logos, which refers to 'repetition' and to 'a relation' or 'a ratio', respectively. ${ }^{1}$ But based on this etymological articulation of the meaning of analogia, it can be inferred that understanding the word necessitates understanding the movements between convertibility and reversibility. Put simply, 'convertibility' refers to the possibility of conversion and change, while 'reversibility' refers to the process of reversal and repetition. This means that the initial relation can be repeated on the one hand; on the other hand, the initial relation can also be reversed and repeated. ${ }^{2}$

But the movements of convertibility and reversibility can also be understood in relation to articulating the relationship between God and beings, which analogia makes linguistically possible. Bonaventure argues, for example, that the similarity or similitudo between the Creator and the creature can be understood as a proportionate one; the creature is related to the Creator in a similar way that an exemplar is related to the exemplatum. ${ }^{3}$ This makes every creature (and, thereby, every being) a vestigium Dei. ${ }^{4}$ Thomas Aquinas supports the similarity between creatures and Creator and refers to this similarity as the arche of analogia. This means that understanding being is a necessary component in our analogical understanding of God. As Thomas Aquinas explains: "... our intellect, since it knows God from creatures, in order to understand God, forms conceptions proportional to the perfections flowing from God to creatures, which perfections pre-exist in God unitedly and simply, whereas in creatures they are received and divided and multiplied." 5

If the thinking of God is made possible by an analogia that is always connected to the metaphysics of 'being,' what becomes of analogia and of our understanding of God in the context of the overcoming of metaphysics and

\footnotetext{
${ }^{1}$ It is worth pointing out that Aristotle's use of the Greek analogia and its cognates, and Thomas Aquinas's use of the Latin analogia, analogice, secundum analogia, and others are different, even if the Latin is a loan word from Greek. Since the paper is interested with Thomas Aquinas's use of analogia (especially in relation to God), it refers to passages in Aristotle where analogia is discussed and whether or not it is relevant to Thomas Aquinas. While there is an Aristotelian counterpart to Thomas Aquinas's analogia, it is worth emphasizing that he might not be using that term, and (perhaps) when Aristotle uses that term, it is not identical with the Thomistic understanding we are interested with.

2 See John R. Betz, Translator's Introduction to Erich Przywara, Analogia Entis: Metaphysics: Original Structure and Universal Rhythm, trans. by John R. Betz and David Bentley Hart (Michigan/Cambridge: William B. Eerdmans Publishing Company, 2014), 30-43.

3 See Etienne Gilson, The Philosophy of Saint Bonaventure, trans. by Dom Illtyd Trethowan and F.J. Sheed (London: Sheed and Ward, 1938).

${ }^{4}$ Bonaventure, The Journey of the Mind to God, trans. by Philotheus Boehner, O.F.M., ed. by Stephen F. Brown (Indiana/Cambridge: Hackett Publishing Company, 1990), 11-17.

${ }^{5}$ Thomas Aquinas, Summa Theologica (All Complete and Unabdriged 3 parts + Supplement $\mathcal{E}$ Appendix + interactive links and annotations), trans. by Fathers of the English Dominican Province (Kindle edition: e-artnow, 2013), Ia. q.13, a.5.
} 


\section{ANALOGIA}

in relation to the ethical shift towards the face of the 'other'? How can we therefore speak of God (who is understood more as 'other' than as 'being')? The paper argues that analogia, understood as convertibility and reversibility, does make possible the retrieval of the meaning of God beyond the overarching metaphysical understanding of 'being' and the ethical conception of the 'other; analogia makes possible an understanding of God as trace. This paper is divided into three parts. The first part discusses analogia as it is understood in relation to the metaphysical 'being' and in terms of the Catholic understanding of the analogia entis. In the second part, we investigate into the possible understanding of analogia as it is understood in relation to the ethical 'other' and the im/possibility of God. The third part engages the dynamics within analogia especially as it addresses the play between the metaphysical understanding of 'being,' the ethical conception of the 'other,' and the implication of this play towards an im/possible articulation of God understood as trace.

\section{Analogies of being}

Originally conceived as a mathematical concept by the Greeks, analogia refers to the proportionate relationship of four different terms. Despite its mathematical origin, the first traces of analogia in philosophy can be seen in the distinction and the play between 'being' and 'difference' and Parmenides and Heraclitus, respectively. It is within this tension and play between 'being' and 'difference' that analogia, especially as it is articulated in the thoughts of Plato and Aristotle, constitutes the attempt to arrive at a mean; it is not accidental, therefore, that Aristotle speaks of analogia as an intermediate (mesotes). ${ }^{6}$ This understanding of analogia as an intermediate is also discernible in Plato's discussion of the changing world as something in between being and non-being (Form and the formless) at the end of Republic Book V. ${ }^{7}$ Moreover, in his treatment of the divided line, Plato analogously refers to the similarity and proportionality between the order of knowledge and the order of being; this is the same as saying that opinion and knowledge are analogous to the distinction between an image and an archetype. The distinction is further made possible by Plato's metaphysical understanding of participation; this means that they are different only in so far as they are related. Plato does not take sides between 'being' or 'difference' (Parmenides and Heraclitus); rather, he uses the distinction between these two ideals to show the superficiality of their supposed oppositions. Difference is a constant

\footnotetext{
${ }^{6}$ Aristotle, The Nicomachean Ethics, trans. by J.A. K. Thomson (London: Penguin Books, 2004), V, 3, 1131b.

7 Plato, The Republic, trans. by Desmond Lee (London: Penguin Books, 2003), 479a480a.

(C) 2019 Mark Joseph T. Calano https://www.kritike.org/journal/issue 25/calano december2019.pdf ISSN 1908-7330
}

(c) $)$ BY-NC-ND 
desire for being; this is saying that there is an analogous relationship between being and becoming and it is a relationship of a difference grounded in difference.

Like his teacher, Aristotle uses analogia as a proportion of four terms. Analogia allows us to compare and contrast beings that are just different, and this relationship that analogia facilitates cannot simply be reduced to a figure of speech. ${ }^{8}$ Aristotle explains that there are three kinds of unity: in number, in species, and in genus. But to these three kinds of unity, he adds a fourth kind; this fourth kind of unity is the proportional unity of things. For Aristotle, this fourth kind of unity can only be possible if there is an indirect relation among things. ${ }^{9}$

Aristotle's analogia is never directly used in relation to being. ${ }^{10}$ But, in arguing that we can speak of being in many ways, he seems to have already used analogia in relation to being. This is discernible in Aristotle's development of what is to be known as a pros hen analogy in the context of health. In this context of health, the 'primary analogate' is the health of the person and all the other senses of the word 'healthy' is a mere derivative. Aristotle compares this analogously to being:

${ }^{8}$ Aristotle, Poetics, trans. by I. Bywater, in The Complete Works of Aristotle, vol. 2, ed. by Jonathan Barnes (Princeton: Princeton University Press, 1984), 1457b16-17. There is a need to create a distinction at this juncture. Metaphor and analogia are not the same. While metaphor is justifiable in poetry and in Scripture, Thomas Aquinas refers to it as the least informative form of discourse (infirma doctrina) (Aquinas, Summa Theologica, Ia, q.1, a.9, obj. 1.). So, while Aristotle in Poetics speaks of four species of metaphor in which analogy belongs, any resolution that can arise on the opposition of metaphor to analogy as proper usage cannot still enlighten us on the nature of the metaphor as such. While Thomas Aquinas (in Summa Theologica, Ia, q.13, a.3 ad 3, Ia, q.13, a.6, and Ia, q.13, a.6) seems to support the view that metaphor is a kind of analogy, there are simply other texts that distinguish the two. For a more thorough treatment of the distinction between metaphor and analogia refer to Ralph McInerny, Aquinas and Analogy (Washington, DC: The Catholic University of America Press, 1996), 116-136. Based on this aporia, it is best not to confuse analogia with the those referred to by Paul Ricoeur [in Paul Ricoeur, The Rule of Metaphor: Multi-disciplinary Studies of the Creation of Meaning in Language, trans. by R. Czerny (London: Routledge, 1978) and in Paul Ricoeur, Interpretation Theory, Discourse and the Surplus of Meaning, trans. by David Pellauer (Forth Worth: The Texas Christian University Press, 1976)] and Jacques Derrida [in Jacques Derrida, "White Mythology: Metaphor in the Text of Philosophy," in Margins of Philosophy, trans. by Alan Bass (Chicago: University of Chicago Press, 1982), 207-271.].

${ }_{9}^{9}$ See Thomas Aquinas, On Being and Essence, trans. by Armand Maurer, 2nd rev. ed. (Toronto, Ontario, Canada: The Pontifical Institute of Medieval Studies, 1968).

${ }^{10}$ Aristotle, Physics, trans. by R. P. Hardie and R. K. Gaye in The Complete Works of Aristotle, vol. 1, ed. by Jonathan Barnes (Princeton: Princeton University Press, 1984), III, 200b32201a3. Aristotle, Metaphysics, trans. by W.D. Ross in The Basic Works of Aristotle, ed. by Richard McKeon (New York: Random House, 1941), IV, 2, 1003a33-b16 \& VII, 4, 1030a16-27. G.E.L. Owen, "Logic and Metaphysics in Some Earlier Works of Aristotle," in Logic, Science and Dialectics: Collected Papers in Greek Philosophy, ed. by Martha Nussbaum (Ithaca: Cornell University Press, 1986), 180-199.

(C) 2019 Mark Joseph T. Calano

https://www.kritike.org/journal/issue 25/calano december2019.pdf

ISSN 1908-7330

(cc)) BY-NC-ND 
Some things are said to be because they are substances, others because they are affections of substance, others because they are a process towards substance, or destructions or privations or qualities of substance, or productive or generative of substance, or of things which are relative to substance, or negations of some of these things or of substance itself. It is for this reason that we even say of non-being that it is non-being. ${ }^{11}$

This makes us speak of a series of analogies among the different senses of being. If there is a horizontal analogous relation in being, then there is also a vertical understanding of analogia.

The analogia of being, although implicit in Plato and Aristotle, is clarified and developed further by Thomas Aquinas (and his followers). In his commentary on Metaphysics (116b-1017a), Thomas Aquinas seems to speak of two kinds of analogia. On the one hand, he speaks of a pros hen type of analogia where two different things are being related to a third and again different thing; this type of analogia is also called the analogia attributionis by other Thomistic commentators, who further elaborated the distinction between intrinsic and extrinsic attribution. On the other hand, Thomas seems to refer to a second type of analogia made possible by comparing two different things that are proportionally similar to two different other things. He writes:

In this way certain things are said analogically and not purely equivocally of God and creatures. Since we can only name God from creatures, as was said earlier, what is said of God and creatures is said insofar as there is some order of the creature to God, as to a principle and cause in which all perfections of things preexist in an excellent manner. ${ }^{12}$

There is no third way. It seems that for Thomas Aquinas, you are either a creature or a Creator. Other Thomistic commentators refer to this type of analogia as the analogia proportionalitas. Undeniably, analogia proportionalitas is very similar to the Greek origin of analogia as a mathematical concept. It is worth pointing out that between these two types of analogia, the second type or analogia proportionalitas properly constitutes what is metaphorical because it implies greater dissimilarity between the different things that are being compared. This is true even when the two types of analogia in Thomas

\footnotetext{
11 Aristotle, Metaphysics, 1457b16-17., IV, 2, 1003b6-11.

12 Thomas Aquinas, Summa Theologica, Ia, q.13, a.5.
} 
Aquinas are really ways of expressing the relationship between different things. ${ }^{13}$

When analogia is used to comprehend the relation between creature and God, Thomas Aquinas seems to speak again of two types of analogia. On the one hand, he seems to have applied analogia within the hierarchy of knowing (ordo cognoscendi); this type of analogia allows us to speak of God epistemologically without really determining and defining God. On the other hand, he also seems to have applied analogia in terms of the hierarchy of being (ordo essendi); this means that we are able to approach God metaphysically without really determining and defining God. These two types of analogia allow us to speak of God without really determining or defining God in a metaphysical and epistemological way.

More concretely, question XIII of the Summa Theologica I presents the analogia that governs the possibility of naming God. In this question, God is given different attributes that do not properly and strictly apply to God because these attributes are drawn from the concrete and created world. These modes of signification that properly apply to creatures but is also applied to God includes, for example, wisdom, life, and goodness. Further in this question, analogia is also used to determine the intermediate (mesotes) between the pure similarity and oneness or 'univocity' and the pure ambiguity and plurality or 'equivocity' of predicated meaning. In understanding analogia within Aristotle's understanding of mesotes as a moving target between two extremes, analogia is able to speak of God within the dynamics (and tension) of univocity and equivocity without reducing God to either/or. This means that the qualities that are used to refer to God cannot be understood in the same way that it is understood when used to creatures. In this sense, we are able to speak of God by possibly referring to God without reduction to the words that used to predicate our understanding of God. As Thomas Aquinas explains: "no name is predicated univocally of God and of creatures," but "neither, on the other hand, are names applied to God and creatures in a purely equivocal sense." 14 Analogia allows us to assert

${ }^{13}$ In referring to God's knowledge, Quaestio disputata de veritate argues that univocity entails pantheism. "Hence it must be said that the word 'knowledge' is predicated of God's knowledge and ours, not wholly univocally, not purely equivocally, but according to analogy, which is to say nothing else than according to proportion. Similarity according to proportion, however, can be twofold, thanks to which there is a twofold community of analogy" (q.2, a.11, c.). Cf. Thomas Aquinas, Truth, Vol. 1 (Questions 1-9), trans. by Robert W. Mulligan (Indianapolis: Hackett Publishing, 1994). In arguing for the similarity of creature to God/Creator, Thomas Aquinas further writes: "There is a kind of similarity where there is among things a proportion, in that they have a determinate distance or other relation between them, as two is twice one. But there can also be a similarity of two things between which there is no proportion, but rather a similarity of two proportions to one another, as six is like four in that six is twice three as four is twice two." Ibid.

${ }^{14}$ Thomas Aquinas, Summa Theologica, I. q. 13, a.5.

(C) 2019 Mark Joseph T. Calano

https://www.kritike.org/journal/issue 25/calano december2019.pdf

ISSN 1908-7330 
that God is revealed in His creation and that He is neither totally unknown nor foreign to us. So, when God is referred to as wise, life, and good, as it was stated above, we do refer to our concrete experiences of wisdom, life, and goodness, but also at the same time, as an overcoming of our concrete experiential references. This means that when we make sense of our experience of God, it is only possible if we refer to realities that are similar to our concrete experiences; but we also know that these concrete references, although similar to our experience of God, is not sufficient to refer to God. This means that although the similarities allow us to speak of God, these similarities still point to a greater dissimilarity between our selves and God. In short, although we are similar to God in many ways, it is also true that, in even greater ways, we are dissimilar to God; no creature can fully resemble God. ${ }^{15}$

When it is a question of a creature resembling God, other Thomistic commentators refer to it as analogia entis. ${ }^{16}$ While Thomas Aquinas never used the term to directly refer to the aforementioned similarity, he seems to have intimated it. In question IV of the Summa Theologica I, Thomas Aquinas responds to the question whether creatures can be considered to be like God. ${ }^{17}$ In responding to the objections in this question, Thomas Aquinas draws his justification from two revealed sources. From the Old Testament, he cites Genesis 1:26 that states, "Let us make humankind in our image, according to our likeness;" and from the New Testament, he cites 1 John 3:2 where we read, "when he is revealed, we will be like him, for we will see him as he is." 18 Although initially grounded in Sacred Scriptures, Thomas Aquinas argues that every created thing is an effect of the Creator. This means that as long as the effects bear some similarity to their cause, then this likeness does constitute the basis for arguing a relationship between creation and God. It is worth noticing, however, that the relationship between creation and Creator is not a relationship between equals; it is obviously an unequal relationship between the cause and the effect. The unequal relationship between Creator and creatures are further distinguished by the fact that God does not share

\footnotetext{
${ }^{15}$ In relation to the human mind's capacity to know God, it can be argued with Thomas Aquinas that: "Proportion, it should be noted, is sued in two ways. In one way, to mean a certain relation of one quantity to another, insofar as double, triple and equal are species of proportion. In another way, any relation of one thing to another is called a proportion. And thus there can be a proportion of creature to God, insofar as it is related to Him as effect to cause and as potency to act. Because of this, the created intellect can be proportioned to know God." Thomas Aquinas, Summa Theologica, Ia, 12, 1, 4m.

${ }^{16}$ See, Przywara, Analogia Entis.

17 Thomas Aquinas, Summa Theologica, Ia, q.4, a.3.

${ }_{18}$ All scriptural references in this essay are drawn from the New Revised Standard Version (NRSV).

(c) 2019 Mark Joseph T. Calano

https://www.kritike.org/journal/issue 25/calano december2019.pdf

ISSN 1908-7330
}

(cc) BY-NC-ND 
any genus; God is neither being nor beings. ${ }^{19}$ Despite this significant difference, God remains to be related to being "according to some sort of analogy; as existence is common to all. In this way, all created things, so far as they are beings, are like God as the first and universal principle of all being." 20

Despite the aforementioned difference between God and being, an analogia of being can still be asserted because of Thomas Aquinas's understanding of creation as an effect of God. As an effect of God, creation can be understood as a trace of God. This means that being as a trace is not totally alien to God; this claim is grounded on the metaphysical understanding that the effect must in some way resemble the cause. But as a trace of God, being cannot totally be like God; this means that the effect is still not the cause. The trace is not God because the trace falls short "not merely in intensity and remission, as that which is less white falls short of that which is more white; but because they are not in agreement, specifically or generically." 21

In short, being or creation is both similar and different to God, our Creator; our relationship with God can only be understood analogically. This analogical relationship cannot simply be understood Thomistically in terms of the similarity between creature and Creator as it can be understood in terms of their dissimilarity. The relationship between God and creature is not reducible simply to God's perfection that is shared and participated by creation. It is worth asserting that God does not have any genus. This means that God can neither be classified nor be understood simply as an instance of something that is commonly shared by both creature and Creator. God transcends every conceivable genus; in Latin, it is stated as Deus non est in genere. Thomas Aquinas explains that while:

it may be admitted that creatures are in some sense like God, it must nowise be admitted that God is like creatures; because, as Dionysius says (Div. Nom. IX): 'A mutual likeness may be found between things of the same order, but not between a cause and that which is caused.' For we say that a statue is like a man, but not

\footnotetext{
${ }^{19}$ Martin Heidegger, "The Onto-theological Constitution of Metaphysics," in Identity and Difference, trans. by Joan Stambaugh (New York: Harper \& Row, 1969), 71. See Jean-Luc Marion, "Thomas Aquinas and Onto-theo-logy," in God without Being, trans. by Thomas A. Carlson (Chicago and London: The University of Chicago Press, 2012), 199-236.

${ }^{20}$ Thomas Aquinas, Summa Theologica, Ia, q.4, a.3.

${ }^{21}$ Ibid.
}

(C) 2019 Mark Joseph T. Calano https://www.kritike.org/journal/issue 25/calano december2019.pdf

ISSN 1908-7330 
conversely; so also a creature can be spoken of as in some sense like God; but not that God is like a creature. ${ }^{22}$

As it was stated in the passage above, Thomas Aquinas recognizes a similarity between cause and effect-between God and creature; but he also recognizes a greater dissimilarity between the two. While the trace of God allows us to intuit God in a way, it does not, however, allows us to intuit God in a definitive and final way. This means that the analogia of being allows us to speak of being and God only in an indirect manner by means of traces. In an age characterized by the 'overcoming of metaphysics,' what becomes of this possibility of referring to being and (even) of engaging God? In broad strokes, it can be said that the analogia of being seems to point to another analogia. This leads us to another possibility within Thomistic scholarshipthe articulation of an analogia that is rooted and grounded in difference. ${ }^{23} \mathrm{I}$ call it the analogia of the other, which is the concern of the second part of this paper.

\section{Analogies of other}

In Thomas Aquinas's intimation of the analogia of the other, I interpret the analogia used by Emmanuel Levinas and discussed by Jacques Derrida. ${ }^{24}$ Quite differently, Levinas discusses his brand of analogia by relating thought to speech. ${ }^{25}$ Instead of determining proportional relationships by means of vision and/or sight, Levinas points to something auditory. If thought is always already linguistic, according to him, then it follows that thought can be equated with speech. From this, Levinas jumps to arguing that thought is, in fact, able to hear the invisible. If thought is able to capture the invisible, then it also follows that speech constitutes a conversation with the invisible; every speaking is therefore a speaking with the invisible. This analogia between thought, speech, and the invisible constitutes the ethical relationship with the invisible other and this is made

\footnotetext{
${ }^{22} \mathrm{Ibid}$.

${ }^{23}$ John Caputo, Heidegger and Aquinas: An Essay on Overcoming Metaphysics (New York: Fordham University Press, 1982), 147-184.

${ }^{24}$ Derrida's understanding of analogia is embedded, but is not limited, to the following texts: Jacques Derrida, "Ousia and Grammē: Note on a Note from Being and Time," in Margins of Philosophy, 29-68; Idem, "Plato's Pharmacy," in Dissemination, trans. by Barbara Johnson (London and New York: The Athlone Press, 2004), 67-186; and Idem, "To Speculate-on 'Freud,'" in The Post Card: From Socrates to Freud and Beyond, trans. by Alan Bass (Chicago: The University of Chicago Press, 1987), 257-410.

${ }^{25}$ Jacques Derrida, "Violence and Metaphysics: An Essay on the Thought of Emmanuel Levinas," in Writing and Difference, trans. by Alan Bass (Chicago: The University of Chicago Press, 1978), 99.

(c) 2019 Mark Joseph T. Calano

https://www.kritike.org/journal/issue 25/calano december2019.pdf

ISSN 1908-7330

(c) BY-NC-ND
} 
possible by speech and discourse. ${ }^{26}$ For Levinas, the other can only be encountered in the context of speech. ${ }^{27}$ Speech makes possible one's relationship to the other; this means that speech makes possible the revelation of the other as an interlocutor. The other is presented as an 'expression' that makes sense only within the context of a linguistic relationship. This linguistic relationship that is always constituted in language is also at the same time constituted by a series of expressions-analogia. It is these series of expressions that facilitate the self-manifestation of the face as a kath' autó. According to Derrida, the self-manifestation and presentation of the Levinasian face is only possible because of the series of similarities and resemblances between our very humanity and God.28 In citing a conclusion from Totality and Infinity, Derrida asserts that the "the other resembles God."29 Arguably, it is within these similarities between humanity and God, and within these resemblances between the human face and the Face of God that humanism and theology draw their impetus. ${ }^{30}$

While Levinas argues that these similarities and resemblances with the other are not always theological and even goes beyond metaphysics, the analogical relationship (as a relating to and with the other) can only be ethical. ${ }^{31}$ This means that in exchange for a metaphysical understanding of the other, Levinas seems to push forward a more ethical relationship. Due to the ethical nature of this analogical relationship, God can only be encountered in the human face by means of his traces; and this encounter cannot simply be reduced to a theological relationship. As such, and going beyond Thomas Aquinas, this ethical relationship cannot be understood (and must never be understood) simply as an analogical knowledge of the different attributes of God. ${ }^{32}$ "There can be no 'knowledge' of God," Levinas argues, "separated from the relationship with men. Other is the very locus of metaphysical truth, and is indispensable for my relations with God." 33 In this sense, Levinas asserts the inseparability of our knowledge of God from our knowledge of the other; our knowledge of God is only possible in and only in our

${ }^{26}$ Throughout Totality and Infinity, Levinas clarifies that the absolutely other is Autrui or totally other: "The absolutely other is Autrui [L'absolument Autre, c'est Autrui.]." Emmanuel Levinas, Totality and Infinity: An Essay on Exteriority, trans. by Alphonso Lingis (Pittsburgh, Pennsylvania: Duquesne University Press, 1969), 39. However, Derrida in "Violence and Metaphysics" uses autrui and l'autre interchangeably; and because Derrida consistently uses the term l'autre in the lowercase, Autrui does not seem to belong to Derrida's vocabulary.

${ }^{27}$ Ibid., 43.

${ }^{28}$ Derrida, “Violence and Metaphysics," 108-109.

${ }^{29}$ Ibid., 108; Levinas, Totality and Infinity, 293.

${ }^{30}$ Derrida, "Violence and Metaphysics," 108.

${ }^{31}$ Levinas, Totality and Infinity, 42.

32 Ibid., 78.

${ }^{33} \mathrm{Ibid}$.

(c) 2019 Mark Joseph T. Calano https://www.kritike.org/journal/issue 25/calano december2019.pdf

ISSN 1908-7330 
relationship with others. It is not possible to arrive at our knowledge of God apart from our relationship with the other - that is, alone and speculatively. While God can only be revealed because of our relationship with the other, Levinas clarifies that the "other is not the incarnation of God, but precisely by his face, in which he is disincarnate, is the manifestation of the height in which God is revealed. It is our relations with men... that give to theological concepts the unique signification they admit of." ${ }^{34}$ Put simply, the other is not God; the other cannot be an incarnation of God. It is this difference between God and the other, however, that makes possible the very revelation of God. In the difference between other and God, God is made manifest. This means, that it is in the context of our ethical (and analogical) relationship with the other, can God and all other theological concepts make sense. While the other is not reducible to God and God is not reducible to the other, God and the other are always related in an analogical and an ethical relationship, which cannot be separated. This means that the revelation of God can only be understood and approached from the perspective of our relationship with the other. Levinas explains this relationship between God and the other in this way: "I cannot describe the relation to God without speaking of my concern for other." He cites Matthew 25:45, where the relation to God is made visible because of our relationship with an other; in the words of Levinas, in the other "is the real presence of God." 35

While Levinas qualifies the relationship between God and the other, Derrida sees and articulates what seems to be a disturbing and a complicitous relationship. ${ }^{36}$ "The face-to-face is thus not originally determined by Levinas as the vis-à-vis of two equal and upright men. The latter supposes the faceto-face of the man with bent neck and eyes raised toward God on high." 37 Derrida accuses Levinas of recognizing that the relationship between God and the other is never of equal and upright partners; instead, it is a relationship between master and his subordinates (or between two different groups). I wish to emphasize two points in this Derridean understanding of the relationship between God and the other. On the one hand, it is worth noting that Derrida agrees with Levinas, and accepts the given and the dependent relationship between God and the other. Derrida criticizes, on the other hand, that this relationship between God and the other is an unequal relationship. But more than a matter of unequality, as if they were always already the same, I agree with Thomas Aquinas and Derrida that this is a

\footnotetext{
${ }^{34} \mathrm{Ibid} ., 77$.

${ }^{35}$ Emmanuel Levinas, “Justice and Love," in Entre nous: Thinking-of-the-Other, trans. by Michael B. Smith and Barbara Harshav (New York: Columbia University Press, 1998), 109-110.

${ }^{36}$ Derrida, "Violence and Metaphysics," 108-109.

${ }^{37}$ Ibid., 107.

(c) 2019 Mark Joseph T. Calano https://www.kritike.org/journal/issue 25/calano december2019.pdf ISSN 1908-7330
}

(c) BY-NC-ND 
matter of difference..$^{38}$ In the similarity and the resemblance between God and the other, God seems to command the other as he conceals God-self; in this sense, it is in the very concealing of God-self, in his very difference, that God unconceals (or reveals) God-self.

Derrida recognizes some evocations of YHWH in Exodus 33:20-23, where speaking with Moses, God says: “But you cannot see my face; for no one shall see me and live ... you shall see my back; but my face shall not be seen." Moses is only allowed to see God's back, but never his face. It is in relation to this scriptural passage that Derrida argues: " $t]$ he face is neither the face of God nor the figure of man: it is their resemblance. A resemblance, which we must think before, or without, the assistance of the same." 39 The above passage puts into question the possibility of the Levinasian face-to-face relation and argues for the impossibility of seeing the face of God. If it is impossible to see the face of God, then it is also impossible to see the true figure of the humanity. ${ }^{40}$ If what is seen is neither the face of God nor the figure of humanity, then what is revealed in the Levinasian face-to-face relation? Derrida clarifies that the face-to-face relation constitutes a similarity or a resemblance between the different God and the other; this analogia is made possible even before the determinations and categories of being.

The analogous relationship between the face of humanity and the figure of God makes possible prayer as a discourse with God. This means that the face-to-face relation between God and the other does not only make ethics possible; it also makes possible speech and prayer as the very condition for the possibility of our relationship between God and the other. Derrida explains:

Via the passageway of this resemblance, man's speech can be lifted up toward God, an almost unheard of analogy which is the very movement of Levinas's discourse on discourse. Analogy as dialogue with God: "Discourse is discourse with God ...." Discourse with God, and not in God as participation. Discourse with God, and not discourse on God and his attributes as theology. ${ }^{41}$

The passage argues that prayer-or one's discourse with God - is only made possible by our resemblance with God. This resemblance allows us to speak

38 See John Caputo, The Prayers and tears of Jacques Derrida: Religion without Religion (Bloomington \& Indianapolis: Indiana University Press, 1997).

${ }^{39}$ Derrida, "Violence and Metaphysics," 109.

40 Jean-Luc Marion, Negative Certainties, trans. by Stephen E. Lewis (Chicago and London: The University of Chicago Press, 2015), 8-50.

${ }^{41}$ Derrida, "Violence and Metaphysics," 108.

(C) 2019 Mark Joseph T. Calano https://www.kritike.org/journal/issue 25/calano december2019.pdf

ISSN 1908-7330 
of prayer as "an almost unheard of analogy." In this case, analogia is understood as the condition for the possibility of our discourse with God. But, this is not a discourse that takes place in God; it is not reducible to a mere participation in God-self. Derrida further clarifies that this prayer is not about God and his attributes; it is not merely and purely theological. Prayer is a discourse and an encounter with God, and this discourse is made possible by our resemblance between humanity and God.

But what is the face (or presence) of God like when understood in terms of this resemblance? Derrida argues that this face (or presence) is a very strange presence. He writes:

Presence as separation, presence-absence as
resemblance, but resemblance which is not the
"ontological mark" of the worker imprinted on his
product, or on "beings created in his image and
resemblance" (Malebranche); a resemblance which can
be understood neither in terms of communion or
knowledge, nor in terms of participation and
incarnation. A resemblance which is neither a sign nor
an effect of God. ${ }^{42}$

This very strange presence comes to us as a resemblance or a trace. As a resemblance (and also a trace), this very strange presence is not the 'ontological mark' of the cause or of the Creator. In fact, it is not even the product of communion or even of knowledge; it is further not the result of participation or of incarnation. This very strange presence or resemblance or analogous relation is not a sign; it is also not an effect of God. This resemblance (which is not everything that has been said so far) situates, positions, and puts us in the 'Trace of God.' 43

This trace or resemblance between humanity and God, which makes possible the determination and revelation of the other, also prohibits the face from appearing in relation to other beings. Why is this so? Derrida clarifies it in this way:

But it is the analogy between the face and God's visage that, in the most classical fashion, distinguishes man from animal, and determines man's substantiality: 'The Other resembles God.' Man's substantiality, which permits him to be face, is thus founded in his

$$
{ }^{42} \text { Ibid. }
$$

(c) 2019 Mark Joseph T. Calano https://www.kritike.org/journal/issue 25/calano december2019.pdf ISSN 1908-7330 
resemblance to God, who is therefore both The Face and absolute substantiality. ${ }^{4}$

For Levinas, the resemblance between God and the human face distinguishes us from the rest of creation. The identification of the God as an other distinguishes us from the rest of creation (living or nonliving). This means that the human face is only possible because of our resemblance with the face of God. This is only possible because what gives humans our face is our resemblance to God; God, in this sense, is understood as absolute substantiality. And when Levinas uses the language of 'substance,' according to Derrida, he is referring to the scholastic problematic of analogia understood as participation, and we are addressing this in the next part. ${ }^{45}$

\section{Trace of God and analogia}

In the second part of the paper, we read that God is better not reduced to a substance or as an ineffable being; God is better not thought of as the final anchor term or as mere presence. God is better understood as an other, in fact-as a totally other. What we know is that God is the most proper of all proper names; as such, God is better thought of as the name of the "endless desertification of language." 46 By referring to the name of God as the "endless desertification of language," we are asserting that the name of God manifests and reflects the analogical nature of language. Because of the analogical nature of language, God's name represents the process and the product of the "movement of the effacement of the trace in presence." 47 Constantly under erasure, the name of God is what remains as traces. This is the same as saying that the name of God can be understood as "a determinant moment in the total movement of the trace." 48 This means that whatever can be said of God remains intelligible only within the play between what is left behind and presented as traces and what is eradicated (if not corrected) by erasure. This is what the statement that God is an "effect of the trace" 49 means; the proper name of God is not and cannot be the trace, it is the effect of the trace. For Derrida, the name of God is the linguistic effect of the endless resemblances

\footnotetext{
${ }^{44}$ Ibid., 142.

${ }^{45}$ Ibid., 143.

${ }^{46}$ Jacques Derrida, "Saufle nom (Post-Scriptum)," in On the Name, ed. by Thomas Dutoit and trans. by David Wood, John P. Leavey, Jr., and Ian McLeod (Stanford, California: Stanford University Press, 1995), 55-56.

${ }^{47}$ Derrida, "Violence and Metaphysics," 108.

${ }^{48}$ Jacques Derrida, Of Grammatology, trans. by Gayatri Chakravorty Spivak (Baltimore: John Hopkins University Press, 1976), 69.

${ }^{49}$ Derrida, "Violence and Metaphysics," 108.
}

(c) 2019 Mark Joseph T. Calano

https://www.kritike.org/journal/issue 25/calano december2019.pdf

ISSN 1908-7330

(cc) BY-NC-ND 
and references of names. ${ }^{50} \mathrm{It}$ is the name that replaces and substitutes an other for another other; in this case, even the name of God, as analogia and as a product of it, can only be subjected as in all other names to the endless play of différance.

The very possibility of infinite and endless substitution constitutes the very possibility for the name God to even become a proper name. The name of God becomes one of the many valid substitutable manifestations of the invisible and unsubstitutable one. The very movement that makes possible this naming of God is responsible for creating the traces that cracks, breaks, or fissures the theological and God concepts of uniqueness, singularity, and unsubstitutability. So while it is said that YHWH cannot be subjected to analogia, it is this very refusal, this uniqueness, and this singularity that any analogia begins. Quite contrary to conceptions of analogia as always related to God and being, Derrida argues that God refuses and denies any analogia with beings. But in this very refusal, in this very interruption, and in this very denial, analogia is initiated, reestablished, and resumed. Just as there is an analogous relationship between the Face of God and the figure of humanity, Derrida continues, there also exists an analogical relationship between every proper name and all attempts to name God. All these names of God and all these proper names are, in their turn, really just analogous between and among themselves. ${ }^{51}$ So, when we argue in this paper that the relation to the other does, in fact, resemble the relation of being to God, what we are not saying is that there is a formal analogia between the two; this is not only an analogical relation with being/same as it is not only an analogical relation with the other. Instead, the play between the other and being resembles a number of attributes and characteristics with who we call God. This is the same as saying that there is an implicit structural relationship (or analogia, if you will) between being, the other, and God.

Analogia constitutes, for Immanuel Kant, a "perfect resemblance or similarity of two relations between two quite dissimilar things." 52 The emphasis is no longer on the similarity (or sameness or identity) as it is on the dissimilarity (or difference). Analogia is understood as a resemblance between two dissimilar things and is concerned with the relations between these two different realities. In the Critique of Judgement, Kant describes analogia as responsible for bridging the abyss between the two absolutely dissimilar and

\footnotetext{
${ }^{50}$ Derrida, "Différance," in Margins of Philosophy, 26-27.

${ }^{51}$ Jacques Derrida, "At This Very Moment in This Work Here I am," in Re-reading Levinas, ed. by Robert Bernasconi and Simon Critchley (Bloomington: Indiana University Press, 1991), 11-48.

${ }^{52}$ Immanuel Kant, Prolegomena to Any Future Metaphysics, trans. by James W. Ellington and Paul Carus (Indianapolis, Indiana: Hacket, 1977), 98.

(c) 2019 Mark Joseph T. Calano https://www.kritike.org/journal/issue 25/calano december2019.pdf ISSN 1908-7330
}

(c) BY-NC-ND 
different worlds - the world of Nature and the world of the Ethical. ${ }^{53}$ As Jacques Derrida comments on this understanding of analogia as a bridge, we read: "the recourse to analogy, the concept and the effect of analogy," in Kant "are or make the bridge itself." 54 This means that analogia does serve as a bridge that connects the gap between a non-negotiable space and distance. Derrida further explains the connection between humanity, God, and analogia: "the principle of analogy is here indeed inseparable from an anthropocentric principle. The human center also stands in the middle, between nature (animate or inanimate) and God." 55

Analogia is anchored on the understanding of a proper name, where it operates as "the nonmetaphorical prime mover of metaphor." 56 As a nonmetaphorical prime mover of every metaphor, analogia restores causality while at the same time it establishes the ground for all other possible relations. This is what Derrida refers to as "ana-onto-logy." Ana-onto-logy refers to a type of analogy that is governed and dominated by the necessity of and impetus to "the appearance as such of the as such, of the as." Because of this impetus and necessity to phenomenality, this type of analogia is governed by the proper name of the logos. The proper name of the logos, aside from determining and articulating the different categories and possibility of thinking, governs externally and, even, beyond language. In this case, the origin of analogia has always already been the logos; for Derrida, this logos "regulates all analogy and which itself is not analogical." ${ }^{57}$

\section{Conclusion}

At the beginning of this paper, we inquired into the im/possibility of analogically (re)presenting God in the context of the overcoming of the metaphysics of 'being' and the advent of the ethics of the 'other.' At this point and as it has been demonstrated broadly in the parts above, we can say that the relationship between being and the other, being and God, and other and God are analogous. But by analogous, we refer it further to something analogous. Being, other, and God all share a certain functional analogia and, thus, can only be inscribed in an open series that contains many other analogous openings and relations. The analogous relationship between the three terms can only remain as something singular, unique, and irreducible,

\footnotetext{
53 Immanuel Kant, Critique of Judgement, trans. by Werner Pluhar (Indianapolis, Indiana: Hacket, 1987), 356.

${ }^{54}$ Jacques Derrida, The Truth in Painting, trans. by Geoffrey Bennington and Ian McLeod (Chicago: The University of Chicago Press, 1987), 36.

55 Ibid., 117. Emphasis mine.

${ }^{56}$ Derrida, "White Mythology," 243.

${ }^{57}$ Jacques Derrida, “Economimesis,” trans. by Richard Klein, Diacritics, 11:2 (Summer, 1981), 19
}

(c) 2019 Mark Joseph T. Calano https://www.kritike.org/journal/issue 25/calano december2019.pdf ISSN 1908-7330 


\section{ANALOGIA}

while, at the same time, offering no guarantee of a perfect resemblance. There is no such thing as a perfect analogia of being, other, and (perhaps) God. It seems that for Thomas Aquinas, Emmanuel Levinas, and Jacques Derrida, the other, being, and God can only be understood as a part of a series of differences and deferences that is also able to comprehend the one, even if they still represent the many. If there is an analogia, therefore, between the relations between and among being, other, and God, then this analogia can only be understood differently. This different analogia can only allow us to combine the economy of analogia (understood as the same that is differed, and deferred) with the rupture of all analogia (or absolute heterology). In this sense, it can only be understood as an analogia that is always interrupted and disturbed. But once this interrupted analogia is further interrupted, it resumes again as an analogia between two or three or more absolute and incommensurable heterogeneities in a continuous movement of convertibility and reversibility.

Department of Philosophy, Ateneo de Manila University, Philippines

\section{References}

Aristotle, Metaphysics, trans. by W.D. Ross in The Basic Works of Aristotle, ed. by Richard McKeon (New York: Random House, 1941).

Physics, The Complete Works of Aristotle, trans. by R. P. Hardie and

R. K. Gaye in The Complete Works of Aristotle, vol. 1, ed. by Jonathan Barnes (Princeton: Princeton University Press, 1984).

Poetics, trans. by I. Bywater, in The Complete Works of Aristotle, vol.

2, ed. by Jonathan Barnes (Princeton: Princeton University Press, 1984).

The Nicomachean Ethics, trans. by J.A. K. Thomson (London: Penguin Books, 2004).

Betz, John R., Translator's Introduction to Erich Przywara, Analogia Entis: Metaphysics: Original Structure and Universal Rhythm, trans. by John R. Betz and David Bentley Hart (Michigan/Cambridge: William B. Eerdmans Publishing Company, 2014).

Bonaventure, The Journey of the Mind to God, trans. by Philotheus Boehner, O.F.M., ed. by Stephen F. Brown (Indiana/Cambridge: Hackett Publishing Company, 1990).

Caputo, John, Heidegger and Aquinas: An Essay on Overcoming Metaphysics (New York: Fordham University Press, 1982).

The Prayers and tears of Jacques Derrida: Religion without Religion

(Bloomington \& Indianapolis: Indiana University Press, 1997).

(C) 2019 Mark Joseph T. Calano

https://www.kritike.org/journal/issue 25/calano december2019.pdf

ISSN 1908-7330

(c) $)$ BY-NC-ND 
Derrida, Jacques, "At This Very Moment in This Work Here I am," in Rereading Levinas, ed. by Robert Bernasconi and Simon Critchley (Bloomington: Indiana University Press, 1991). "Economimesis," trans. by Richard Klein, Diacritics, 11:2 (Summer, 1981). Of Grammatology, trans. by Gayatri Chakravorty Spivak (Baltimore: John Hopkins University Press, 1976). "Ousia and Grammē: Note on a Note from Being and Time," in Margins of Philosophy, trans. by Alan Bass (Chicago: University of Chicago Press, 1982).

"Plato's Pharmacy," in Dissemination, trans. by Barbara Johnson (London and New York: The Athlone Press, 2004). "Sauf le nom (Post-Scriptum)," in On the Name, ed. by Thomas Dutoit and trans. by David Wood, John P. Leavey, Jr., and Ian McLeod (Stanford, California: Stanford University Press, 1995). , The Truth in Painting, trans. by Geoffrey Bennington and Ian McLeod (Chicago: The University of Chicago Press, 1987). To Speculate-on 'Freud,'"' in The Post Card: From Socrates to Freud and Beyond, trans. by Alan Bass (Chicago: The University of Chicago Press, 1987).

"Violence and Metaphysics: An Essay on the Thought of Emmanuel Levinas," in Writing and Difference, trans. by Alan Bass (Chicago: The University of Chicago Press, 1978).

"White Mythology: Metaphor in the Text of Philosophy," in Margins of Philosophy, trans. by Alan Bass (Chicago: University of Chicago Press, 1982).

Gilson, Etienne, The Philosophy of Saint Bonaventure, trans. by Dom Illtyd Trethowan and F.J. Sheed (London: Sheed and Ward, 1938).

Heidegger, Martin, "The Onto-theological Constitution of Metaphysics," in Identity and Difference, trans. by Joan Stambaugh (New York: Harper \& Row, 1969).

Kant, Immanuel, Critique of Judgement, trans. by Werner Pluhar (Indianapolis, Indiana: Hacket, 1987). Prolegomena to Any Future Metaphysics, trans. by James W. Ellington and Paul Carus (Indianapolis, Indiana: Hacket, 1977).

Levinas, Emmanuel, "Justice and Love," in Entre nous: Thinking-of-the-Other, trans. by Michael B. Smith and Barbara Harshav (New York: Columbia University Press, 1998).

Totality and Infinity: An Essay on Exteriority, trans. by Alphonso Lingis (Pittsburgh, Pennsylvania: Duquesne University Press, 1969).

Marion, Jean-Luc, Negative Certainties, trans. by Stephen E. Lewis (Chicago and London: The University of Chicago Press, 2015).

(C) 2019 Mark Joseph T. Calano

https://www.kritike.org/journal/issue 25/calano december2019.pdf

ISSN 1908-7330 


\section{ANALOGIA}

"Thomas Aquinas and Onto-theo-logy," in God without Being, trans. by Thomas A. Carlson (Chicago and London: The University of Chicago Press, 2012).

McInerny, Ralph, Aquinas and Analogy (Washington, DC: The Catholic University of America Press, 1996).

Owen, G.E.L., "Logic and Metaphysics in Some Earlier Works of Aristotle," in Logic, Science and Dialectics: Collected Papers in Greek Philosophy, ed. by Martha Nussbaum (Ithaca: Cornell University Press, 1986).

Plato, The Republic, trans. by Desmond Lee (London: Penguin Books, 2003).

Przywara, Erich, Analogia Entis: Metaphysics: Original Structure and Universal Rhythm, trans. by John R. Betz and David Bentley Hart (Michigan/Cambridge: William B. Eerdmans Publishing Company, 2014).

Ricoeur, Paul, Interpretation Theory, Discourse and the Surplus of Meaning, trans. by David Pellauer (Forth Worth: The Texas Christian University Press, 1976).

The Rule of Metaphor: Multi-disciplinary Studies of the Creation of Meaning in Language, trans. by R. Czerny (London: Routledge, 1978).

Thomas Aquinas, On Being and Essence, trans. by Armand Maurer, 2nd rev. ed. (Toronto, Ontario, Canada: The Pontifical Institute of Medieval Studies, 1968).

Summa Theologica (All Complete and Unabdriged 3 parts + Supplement $\mathcal{E}$ Appendix + interactive links and annotations), trans. by Fathers of the English Dominican Province (Kindle edition: e-artnow, 2013).

Thomas Aquinas, Truth, Vol. 1 (Questions 1-9), trans. by Robert W. Mulligan (Indianapolis: Hackett Publishing, 1994).

(C) 2019 Mark Joseph T. Calano

https://www.kritike.org/journal/issue 25/calano december2019.pdf

ISSN 1908-7330

(cc) BY-NC-ND 